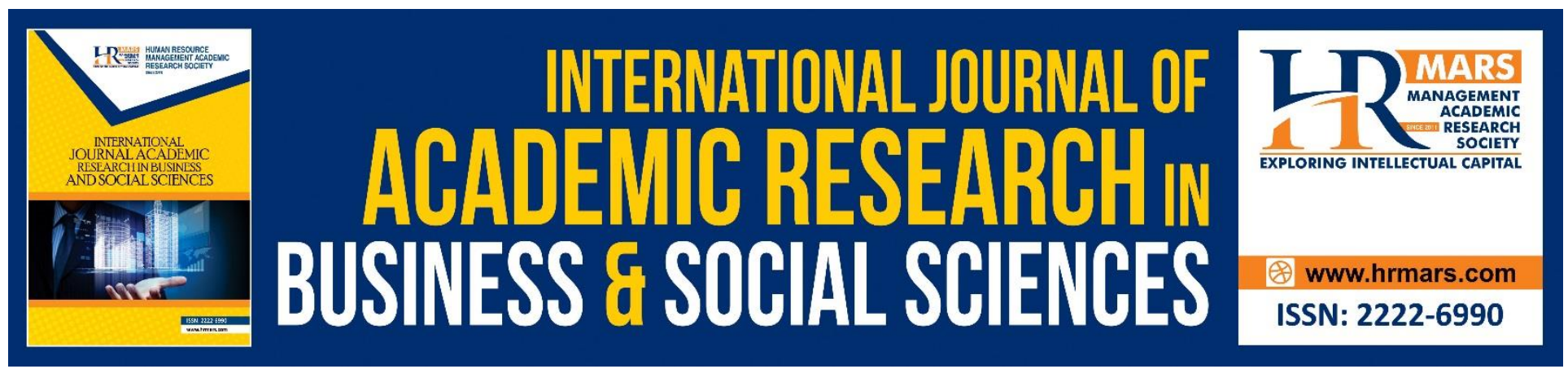

\title{
Bar Model Method for Higher Order Thinking Skills Questions in Mathematics for Dual Language Program Pupils
}

Ragu Ramasamy and Marzita Puteh

To Link this Article: http://dx.doi.org/10.6007/IJARBSS/v8-i9/4855

DOI: $\quad 10.6007 /$ IJARBSS/v8-i9/4855

Received: 11 August 2018, Revised: 08 Sept 2018, Accepted: 29 Sept 2018

Published Online: 04 October 2018

In-Text Citation: (Ramasamy \& Puteh, 2018)

To Cite this Article: Ramasamy, R., \& Puteh, M. (2018). Bar Model Method for Higher Order Thinking Skills Questions in Mathematics for Dual Language Program Pupils. International Journal of Academic Research in Business and Social Sciences, 8(9), 1456-1462.

Copyright: (C) 2018 The Author(s)

Published by Human Resource Management Academic Research Society (www.hrmars.com)

This article is published under the Creative Commons Attribution (CC BY 4.0) license. Anyone may reproduce, distribute, translate and create derivative works of this article (for both commercial and non-commercial purposes), subject to full attribution to the original publication and authors. The full terms of this license may be seen

at: http://creativecommons.org/licences/by/4.0/legalcode

Vol. 8, No. 9, September 2018, Pg. 1456 - 1462

http://hrmars.com/index.php/pages/detail/IJARBSS

JOURNAL HOMEPAGE

Full Terms \& Conditions of access and use can be found at http://hrmars.com/index.php/pages/detail/publication-ethics 


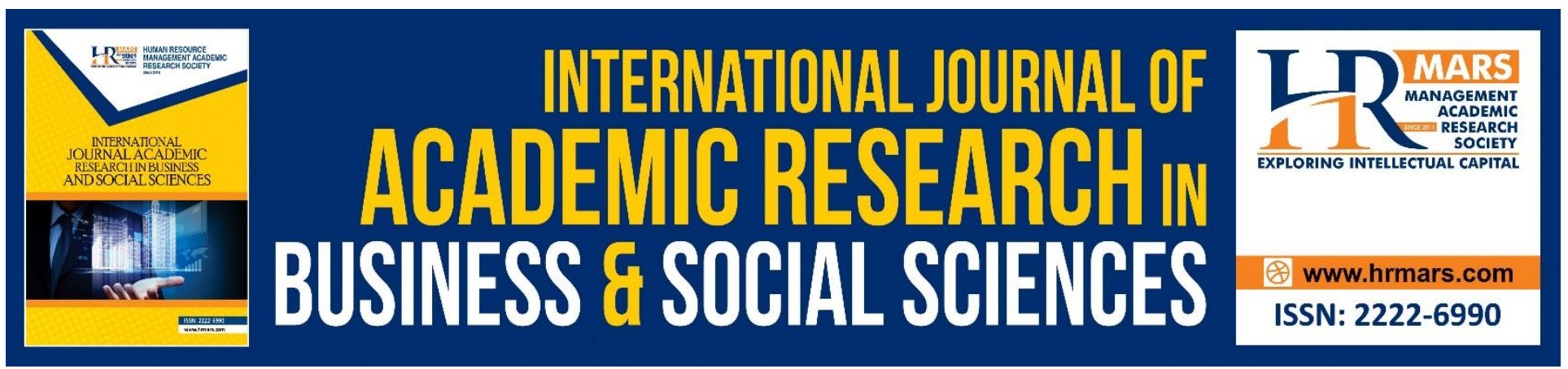

\title{
Bar Model Method for Higher Order Thinking Skills Questions in Mathematics for Dual Language Program Pupils
}

\author{
Ragu Ramasamy and Marzita Puteh \\ Faculty of Science and Mathematics, UPSI, Malaysia
}

\section{Abstract}

Malaysia intense to achieve high aspirations in global competitive environment and the transformation in the delivery of teaching and learning are much needed. This study was to examine the effectiveness of Bar Model representative to solve the Mathematics Higher Order Thinking Skills (HOTS) question for year 6 Dual Language Program (DLP) class pupils at SK Bukit Bandaraya. The study involved 35 pupils from years 6 DLP class at SK Bukit Bandaraya. The focus of the study is to examine the effectiveness using Bar Model method to understand and answer HOTS questions for primary school pupils. This is a qualitative experimental research and the effectiveness of this method will be analyzed through the findings from pre and post questionnaires of the researchers in the actual classroom. Discussion of the findings of this study is based on pupil's result in pre and post test result. The results of this study will hopefully provide some information to educators in choosing the method that can improve student's understanding in order to answer HOTS questions.

Keywords: Bar Model, Higher Order Thinking Skills (HOTS) , Dual Language Program (DLP), Year 6 Pupils

\section{Introduction}

As a human being, we think spontaneously but it does mean that our thinking is as effective as we think. When as an educator wants to teach our pupils how to think, what can be done to improve the quality of their thinking. Everyone is able to think on low-level thinking. Proper exposure, adjustment, guidance and encouragement enable us to think at a higher level of thinking (Rajendran, 2017). Malaysia is competing globally in a fierce globalization and in order to achieve a high aspiration in the global world, transformation in the field of teaching and learning delivery is indispensable. Focus should be given in new aspects of implementation and approach and strategy, so that individuals can master the skills needed to meet the challenges of the 21st century. Today, in context of world education is extremely challenging nowadays, that the younger generation who are knowledgeable, able to think critically and creatively, and are able to communicate effectively on a global level should be shaped by the education system in Malaysia (Marzita et. al, 2017). 
INTERNATIONAL JOURNAL OF ACADEMIC RESEARCH IN BUSINESS AND SOCIAL SCIENCES Vol. 8, No. 9, Sept. 2018, E-ISSN: 2222-6990 @ 2018 HRMARS

Approaches and new strategies in teaching and learning are needed so that pupils able to master the skills in line with the development of science and technology to meet the challenges of the 21st century. Mathematics education requires a changes or transformation in terms of purpose, content, approach and evaluation. According to Nik Aziz (2009), this aspect needs to be compiled and assessed to unite with the relevance of content delivery that involves factual knowledge, conceptual knowledge, procedural knowledge and strategic knowledge. As an educator, we need to do changes in method to increase knowledge of our pupils in mathematics.

Higher Order Thinking Skills (HOTS) application in teaching and learning not only meet the National Education Philosophy to produce a balanced and harmonious individuals intellectually, spiritually, emotionally and physically, but also it is a humanitarian responsibility by teachers to pupils(Curriculum Development Centre, 2012) .The role of teachers are very important in producing well-balanced students. In planning and delivering of teaching and learning, teachers must be base on Philosophy of Education and supported by the Malaysian Education Development Blueprint. Accordingly, HOTS should be applied in all points of subjects. Therefore, mastery in HOTS is very important to be applied in learning and teaching in all subjects in order to prepare pupils to be able in dealing with complex life (The Examination Board of the Ministry of Education, 2013) and be able to have a high level of reasoning as well as helping pupils to answer questions with high-level thinking. In this current era, pupils are facing difficulty to understand and solve HOTS questions.

Famous researcher in Bar Model Yeap Ban Har (PhD) is a principal at an institute in Singapore as an important individual in the review of the National Mathematics Curriculum of Singapore. In an article promoting mathematical communication, Yeap (2008) focuses more on the curriculum in the intended, implied and explicit Singapore curriculum. In his writing, he stated, "The Mathematical Curriculum in Singapore targets mathematical problem solving as the primary objective. In addition, this developed curriculum focuses on helping pupils to develop their ability to provide logical explanations, to communicate in mathematics and to learn to work together and learn independently. Textbooks in Singapore as well as in-class assessments and Primary Leaving School Exam examinations play an important role in ensuring the accuracy of the ongoing mathematical communication. Yeap (2008) emphasized that the use of the Bar Model Method gives pupils the means to deal with information, dealing with information complexity and at the same time channeling their views through the visuals they can manipulate.

Bar Model method is best suited to solve problems involving comparisons, partial and full computations, ratios, proportions and exchange rates (Hoven \& Garelick, 2007), where all of these operations are particularly important in solving mathematical problems. One aspect of the strength of this method is that it is extremely versatile, as well as having a simple visual and easy to draw and understand. Model Bar is developed from a set of generator series in rectangular form where its mathematical quantities consist of known and unknown quantities and their relationship to the problem is presented in real terms (Ho \& Lowrie, 2014). This visual clarity helps pupils to move towards making the right decisions in various contexts of mathematical problems. 
INTERNATIONAL JOURNAL OF ACADEMIC RESEARCH IN BUSINESS AND SOCIAL SCIENCES Vol. 8, No. 9, Sept. 2018, E-ISSN: 2222-6990 @ 2018 HRMARS

Launched on 6 September 2013, Malaysian Education Blueprint (2013-2025), overseen by Education Performance and Delivery Unit (PADU) under the ministry of Education, consisted of 11 shifts and 55 key initiatives to transform the system. Pertaining to English proficiency, MBMMBI policy or Memartabatkan Bahasa Malaysia \& Memperkukuh Bahasa Inggeris (which means to uphold Malay and to strengthen the English language) introduced to replace PPSMI. MBMMBI designed to ensure the usage of Malay as a medium of communication in all national schools and secondary schools, at the same time to make sure that each child can master both Malay and English languages.

Under the umbrella of MBMMBI policy, Dual Language Program was introduced. It is a program where schools are given the choice to offer the teaching and learning of STEM (specifically Mathematics, Science, Design Technology and ICT) subjects in English or Malay. The pilot phase started in January 2016 and involved 300 primary and secondary schools that are ready in terms of teaching and administrative resources and parental engagement. This program has two aims: 1 . to reinforce mastery of English through increased contact time with English language 2. with the strong bilingual background, pupils are hope to increase their access and exploration of knowledge in order to be globally competitive and to increase their competitiveness in the workforce (Ministry of Education Malaysia, 2015).

Possession of pupils in higher-order thinking skills for primary school mathematics should be given a serious attention. Educators need to find solutions or measures to implement the thinking skills of students. The researchers took steps to make this study to see the effectiveness of visualization using Bar Model representative to solve HOTS questions for year 6 DLP class.

\section{Problem Statement}

Our Malaysian pupils education level has not yet reached the international level, but it is more exciting to note that Malaysia's ranking is less favorable in international assessments such as TIMSS (Trends in International Mathematics and Science Study) and PISA (Program for International Pupils Assessment) analysis. TIMSS is an international assessment of mathematics and science that measures knowledge content and cognitive skills of grade 4 (10 years) and grade 8 (14 years) students. While PISA is an international assessment to measure knowledge in reading, mathematics and science for kids aged 15 years.

The TIMSS and PISA 2015 reports released by Ministry Of Education (2016), indicate our country is lagging behind in terms of scores obtained which have not yet reached the average international score set. Focusing on Malaysia's achievement for mathematics in TIMSS, until 2015 Malaysia cannot achieve a set of internationally-defined scores of 500. In 2007, Malaysia scored 474 scores, downgrading to 440 scores in 2011 and the latest Malaysia scored 465 scores in 2015. The average PISA score for Mathematics is 490, which is also unreachable to us. The report of Ministry Of Education (2016) for PISA also shows that our country scored 404 scores in 2009, in 2012 it earned 421 scores and the latest in 2015 gained 446 scores. Malaysian Education Minister in 2016, stated that Malaysia's results for TIMSS and PISA were still less promising but expected to get better results 
INTERNATIONAL JOURNAL OF ACADEMIC RESEARCH IN BUSINESS AND SOCIAL SCIENCES

Vol. 8, No. 9, Sept. 2018, E-ISSN: 2222-6990 (C) 2018 HRMARS

in the future. Analysis of TIMSS and PISA clearly indicates that our Malaysian students are less capable of applying HOTS.

Abdullah (2015), found that the main challenge of the teacher was to identify the way in which and to carry out lessons that can ensure HOT's objectives can be achieved. The right method is able to generate critical and creative thinking of students which in turn is able to increase their four HOTs levels (Masanah, 2014). Teachers today are still focusing on memorizing various concepts, theorems and formulas in mathematics and focusing on the correct answers to mathematical problem solving without emphasizing the ability of students to understand the concepts and deepen the concept by using the existing knowledge and experience of students in solving problems involving HOTs questions.

\section{Research Objective}

The main objective of this study is find out the effectiveness of Bar Model method in solving problem solving questions involving HOTs.

\section{Research Methodology}

This study was to examine the effectiveness of bar model method to solve HOTS questions for students in year 6 DLP class in SK Bukit Bandaraya, Bangsar, Kuala Lumpur. To see the effectiveness of the Bar Model method, experimental testing methods through pre and posttest without control group was carried out. There are four HOTS questions in the pre and post test .The pretest need to be answered by the students before the Workshop Using Bar Model for HOTS Questions and the post test is after the Workshop ends. The findings of the pre and post test were analyzed by using SPSS software version 22 to see the differences between the pre and posttests, the average changes and the average percent changes. Therefore, T-test was to analyze the data.

\section{Finding \& Discussion}

Table 1 shows the findings been analyzed by using SPSS version 22 for pre and post test results. The results of the pre and post show differences in average mean scores of 9.71 to 68.40. indicates the number of students involved in this study, which were 35 students from year 6 DLP class. This finding shows that the Bar Model method was effective for the students.

\section{Table 1. One Sample T-Test}

\begin{tabular}{|c|c|c|c|c|}
\hline Type Of Test & $\mathrm{N}$ & Mean & $\begin{array}{c}\text { Standard } \\
\text { deviation }\end{array}$ & T-value \\
\hline Pre Test & 35 & 9.7143 & 8.536 & 6.733 \\
\hline Post Test & 35 & 68.400 & 22.995 & 17.598 \\
\hline \multicolumn{3}{|c}{$\mathrm{P}=0$} \\
\hline
\end{tabular}


From the observation, the researcher and teachers found that by using bar model kits, the students pay more attention in the topic discussed. The students enjoy the lesson using the Bar Model Kits to solve mathematic questions. At the beginning, students had some problem to estimate the size of bar according to its values. Later, with more practices on direct questions, they were able to estimate values correctly. The duration of three hours to cover four topics (addition, subtraction, multiplication and division) was not sufficient according to the observation.

From the interviews between the researcher and the students, the researcher noticed that majority students agreed that they enjoyed solving questions using bar model especially using bar model kits. Students prefer more time doing the questions with the kits given.

\section{CONCLUSION}

As a conclusion, Bar Model representative for HOTS questions affect students achievements. Students can convert problem questions to bar representatives and this gives a clear picture to the student to find the best solution for the questions. The time factor becomes a constraint to the implementation of this workshop. In the future, researcher would reduce the topic from four into two so that students can master the skills taught and do more practices using bar model kits.

\section{Acknowledgement}

Prof. Dr. Marzita Puteh

Faculty Of Science \& Mathematics, Universiti Pendidikan Sultan Idris, Tanjung Malim, Perak.

\section{Corresponding Author}

Prof. Dr. Marzita Puteh

Email: marzita@fsmt.upsi.edu.my

\section{References}

Curriculum Development Centre (2002). Kemahiran Berfikir Dalam Pengajaran Dan Pembelajaran. Pusat Perkembangan Kurikulum, Kementerian Pendidikan Malaysia.

Curriculum Development Center (2012), Dokumen Standard Kurikulum dan Pentaksiran Matematik Tahun 4. Putrajaya.

Examination Board of the Ministry of Education (2013). 11 Anjakan yang Terkandung dalam Pelan Pembangunan Pendidikan 2013-2025, 1-25.

Ho, S. Y., \& Lowrie, T. (2014). The model method: Students' performance and its effectiveness. Journal of Mathematical Behavior, 35, 87-100. 
INTERNATIONAL JOURNAL OF ACADEMIC RESEARCH IN BUSINESS AND SOCIAL SCIENCES

Vol. 8, No. 9, Sept. 2018, E-ISSN: 2222-6990 (C) 2018 HRMARS

Hoven, J., \& Garelick, B. (2007). Singapore math: Simple or complex Educational Leadership, 65, 2831.impact of the implementation of thinking skills approaches on pupils, in Research in Education Library, London: EPPI-Centre, Social Science.

Ministry of Education. (2015). Executive Summary Malaysia Education Blueprint 2013-2025 (Preschool to Post-Secondary Education). [online] Available at: http://www.moe.gov.my/cms/upload_files/articlefile/2013/articlefile_file_003114.pdf [Accessed 2 Aug. 2015].

Ministry of Education Malaysia (MOE), Laporan Awal Pelan Pembangunan Pendidikan Malaysia 2013-2025, Putrajaya: Ministry of Education Malaysia

Ministry Of Education (2016) PISA 2015. Bahagian Perancangan dan Penyelidikan Dasar Pendidikan Kementerian Pendidikan Malaysia

Azis, N. P. N. (2009). Nilai Dan Etika Dalam Pendidikan Matematik. Kuala Lumpur. Universiti Malaya Rajendran. (2017). Pengajaran dan Pengurusan Kemahiran Berfikir Aras Tinggi. Teori dan Amalan. Penerbit UPSI

Yeap, B. H. (2008). The Singapore Mathematics Curriculum And Mathematical Communication. Available online at www.criced.tsukuba.ac.jp/math/apec2008/papers/PDF/13. Yeap BanHar_Singapore.pdf 